\title{
Retrospective Analysis of Patients with Isolated Hand Injuries Admitted to the Emergency Department
}

\section{Acil Servise Başvuran ve İzole El Yaralanması Olan Hastaların Retrospektif Analizi}

\author{
Ahmet ÇAĞLAR $^{1}(\mathbb{D})$, illker KAÇER ${ }^{1}(\mathbb{D})$, Mehmet Ali ERYAZĞAN ${ }^{2}$ \\ ${ }^{1}$ Aksaray University Training and Research Hospital, Department of Emergency Medicine, Aksaray, TURKEY \\ ${ }^{2}$ Aksaray University School of Medicine, Department of Thoracic Surgery, Aksaray, TURKEY
}

\section{Abstract}

Background: Hand and wrist injuries account for approximately $10 \%$ of all emergency department admissions. Hand traumas, especially hand fractures, are associated with social deprivation except in very young and very old individuals. In this study, we aimed to evaluate the clinical characteristics, risk factors, and the effect of injury on the life of patients admitted to the emergency department for an isolated hand injury.

Materials and Methods: Patients who were admitted to the emergency department due to an isolated hand injury between 1 November 2019 and 1 November 2020 were included in the study. Multivariate logistic regression analysis was used to determine the risk factors of permanent disability.

Results: The study included 205 patients with a mean age of $28.05 \pm 10.85$ years, and 142 (69.3\%) of them were male. The vast majority of patients $(n=149 ; 72.7 \%)$ were in the $18-35$ years age group. The mechanism of injury was blunt trauma in $131(63.9 \%)$ patients and penetrating trauma in $65(31.7 \%)$ patients. Amputation was necessary in $25(12.2 \%)$ patients, and $20(9.8 \%)$ patients had a permanent disability. Results of the logistic regression analysis revealed that male sex and penetrating trauma were independent risk factors for permanent disability $(p=0.012$ and $p<0.001$, respectively).

Conclusions: Evaluation of hand injuries and related factors in our region is important because the results can vary between regions due to differences in lifestyle and working conditions. We found that male sex and penetrating trauma are independent risk factors for permanent disability in patients with isolated hand injury. Preventive measures against such injuries could reduce the permanent disability and related mental and economic burden.

Key Words: Emergency department, Home accident,Isolated hand injury, Night shift, Occupational injury

öz.

Amaç: El ve el bileği yaralanmaları, tüm acil servis başvurularının yaklaşık \%10'unu oluşturmaktadır. El travmaları, özellikle el kıııları, çok genç ve çok yaşlı bireyler dışında sosyal yoksunluk ile ilişkilidir. Bu çalışmada izole el yaralanması ile acil servise başvuran hastaların klinik özelliklerini, risk faktörlerini ve yaralanmanın yaşam üzerindeki etkilerini değerlendirmeyi amaçladık.

Materyal ve Metod: Çalışmaya, 1 Kasım 2019 ile 1 Kasım 2020 tarihleri arasında izole el yaralanmas nedeniyle acil servise başvuran hastalar dahil edildi. Kalıcı engellilik durumunun risk faktörlerini belirlemek için çok değişkenli lojistik regresyon analizi kullanıldı.

Bulgular: Çalışmaya yaş ortalaması $28,05 \pm 10,85$ yıl olan 205 hasta dahil edildi ve bunların 142'si (\%69,3) erkekti. Hastaların büyük çoğunluğu $(n=149, \% 72,7) 18-35$ yaş grubundaydı. Yaralanma mekanizması 131 $(\% 63,9)$ hastada künt ve $65(\% 31,7)$ hastada penetran travmaydı. $25(\% 12,2)$ hastada ampütasyon gerekliydi ve $20(\% 9,8)$ hastada kalıcı engellilik durumu mevcuttu. Lojistik regresyon analizinin sonuçları, erkek cinsiyet ve penetran travmaların kalıı engellilik durumu için bağımsız risk faktörleri olduğunu gösterdi (sırasıyla; $p=0,012$ ve $p<0,001$ ).

Sonuç: Bölgemizdeki el yaralanmaları ve ilgili faktörlerin değerlendirilmesi önemlidir çünkü sonuçlar, yaşam tarzı ve çalışma koşullarındaki farklııklar nedeniyle bölgeler arasında farkılık gösterebilmektedir. Çalışmamızın sonuçları, izole el yaralanması olan hastalarda erkek cinsiyet ve penetran yaralanmaların kalııı engellilik için bağımsız risk faktörleri olduğunu göstermiştir. Bu tür yaralanmalara karşı alınacak önleyici tedbirlerin, kalıcı engellilik ve buna bağlı ruhsal ve ekonomik yükü azaltabileceğini düşünüyoruz.

Anahtar kelimeler: Acil servis, Ev kazası, Gece vardiyası, i̇ş kazası, i̇zole el yaralanması
Corresponding Author/Sorumlu Yazar

Dr. Ahmet ÇAĞLAR

Aksaray University Training and

Research Hospital, Department of

Emergency Medicine

Coglaki Mahallesi 1206. Sokak Park

Mahall Sitesi, 68200, Aksaray, TURKEY

E-mail: drcaglar4@gmail.com

Received / Geliş Tarihi: 21.02.2021

Accepted / Kabul Tarihi: 07.04.2021

DOI: 10.35440/hutfd.884096 


\section{Introduction}

The hand is a unique organ. We use our hands for almost all our daily life activities and therefore it is the most susceptible to injury (1). Distal upper extremity injuries can vary from simple lacerations to a severely crushed hand including soft tissue and nervous and vascular structures $(1,2)$. Hand and wrist injuries account for approximately $10 \%$ of all emergency department (ED) admissions (3). Most of the patients with minor injuries recover without dysfunction in a short time period, whereas patients with complicated injuries require a long treatment duration (4). Hand traumas, especially hand fractures, are associated with social deprivation except in very young and very old individuals (5).

While work accidents are the most common cause of hand injuries in developing countries, home accidents are more common in developed countries $(6,7)$. Work-related hand injuries are usually caused by a mechanical force. Burn, chemical exposure, and electric shock are other injury mechanisms (8). The risk factors include carelessness, lack of maintenance of workplace equipment, lack of personal protective equipment, long working hours, hurry to get the work done, and lack of appropriate training (9).

The clinical features and risk factors of hand injuries can vary between countries, even between regions in the same country. However, hand injuries have not been evaluated previously in our region. Therefore, this study was conducted to evaluate the clinical characteristics, risk factors, and the effect of injury on the life of patients who were admitted to the ED with an isolated hand injury.

\section{Materials and Methods}

This retrospective study was carried out in the ED of a regional academic hospital that provides tertiary healthcare services. The study was conducted in compliance with the Declaration of Helsinki and approved by the regional ethics committee (2020/13-48).

Patients who were admitted to the ED due to an isolated hand injury between 1 November 2019 and 1 November 2020 were included in the study. Patients with missing data, with an injury in a part other than the forearm, and with a previous hand injury history were excluded from the study. In addition to the age and sex, time of injury (day or night), cause of injury (fall, home accident, work accident, assault, or traffic accident), mechanism of injury (blunt, penetrating, burn, chemical exposure, or electric shock), injury side (dominant or non-dominant hand), fracture, tendon injury, administered treatment, amputation, and permanent disability were retrospectively reviewed.

Statistical analysis

The data were analyzed using the SPSS (version 22.0) program. Descriptive data are expressed as n (\%) for categorical variables and as mean \pm standard deviation (SD) for the non-categorical variable (age). The primary endpoint was permanent disability. Factors affecting permanent disability were compared using the chi-square or Fischer's exact test. The parameters that had a p-value of $<0.2$ in the comparison were included in the multivariate logistic regression model. The backward conditional method was used in the regression model. A p-value of $<0.05$ was considered to indicate statistical significance.

\section{Results}

During the study period, 235 patients were admitted to the ED with an isolated hand injury. Thirty patients were excluded due to missing data, and finally, 205 patients were included in the study. The mean age was $28.05 \pm$ 10.85 years, and $142(69.3 \%)$ patients were male. While most patients ( $n=149,72.7 \%$ ) were between 18 and 35 years, there were $24(11.7 \%)$ patients under 18 years, and $32(15.6 \%)$ patients were over 35 years. In terms of time of admission to the ED, 180 (87.8\%) patients were admitted to the ED within the first hour after injury, 17 (8.3\%) patients within 1-6 hours, and $8(3.9 \%)$ patients within 624 hours.

Hand injuries were more common ( $n=108,52.7 \%$ ) during the daytime (08:00-16:00). The most common cause of hand injury was home accidents ( $n=59,28.8 \%$ ), followed by work accidents ( $n=52,25.4 \%)$, and falls ( $n=50,24.4 \%)$. The mechanism of injury was blunt trauma in 131 (63.9\%) patients and penetrating trauma in 65 (31.7\%) patients. Hand injuries were more common in the non-dominant hand ( $n=107,52.2 \%)$. Bone fracture was observed in 38 (\%18.5) patients, tendon damage in 35 (17.1\%) patients, and nerve damage in 10 (4.9\%) patients. While non-steroidal anti-inflammatory drugs were sufficient for most patients ( $n=94,45.9 \%), 37(18 \%)$ patients required surgical intervention. Amputation was necessary in 25 (12.2\%) patients, and 20 (9.8\%) patients had a permanent disability. The injury characteristics of the patients are summarized in Table 1.

In the comparison of patients with and without amputation, there was a statistically significant difference in terms of age, sex, and mechanism of injury ( $p=0.021, p=$ 0.03 , and $p<0.001$, respectively). There was no statistically significant difference in terms of cause of trauma, time of admission, and dominant hand $(p=0.127, p=$ 0.332 , and $p=0.404$, respectively; Table 2 ).

Table 3 presents the comparison of patients with and without permanent disability. There was a statistically significant difference in terms of age $(p=0.018)$, sex ( $p=$ $0.034)$, cause of injury ( $p=0.03)$, and mechanism of injury $(p<0.001)$. There was no statistically significant difference in terms of time of admission $(p=0.103)$ and dominant hand $(p=0.462)$. 
Table 1. Characteristics of isolated hand-injuries

\begin{tabular}{|c|c|}
\hline Age, years, mean $\pm S D$ & $28.05 \pm 10.85$ \\
\hline \multicolumn{2}{|l|}{ Age group, years, $\mathrm{n}(\%)$} \\
\hline $18-35$ & $149(72.7)$ \\
\hline Others & $56(27.3)$ \\
\hline \multicolumn{2}{|l|}{ Sex, n (\%) } \\
\hline Male & $142(69.3)$ \\
\hline Female & $63(30.7)$ \\
\hline \multicolumn{2}{|c|}{ Time spent from injury to admission, hours, $\mathrm{n}(\%)$} \\
\hline $0-1$ & $180(87.8)$ \\
\hline $1-6$ & $17(8.3)$ \\
\hline $6-24$ & $8(3.9)$ \\
\hline \multicolumn{2}{|l|}{ Admission time, $\mathrm{n}(\%)$} \\
\hline 00:00-08:00 & $23(11.2)$ \\
\hline 08:00-16:00 & $108(52.7)$ \\
\hline 16:00-00:00 & $74(36.1)$ \\
\hline \multicolumn{2}{|l|}{ Cause of trauma, $\mathrm{n}(\%)$} \\
\hline Home accident & $59(28.8)$ \\
\hline Work accident & $52(25.4)$ \\
\hline Fall & $50(24.4)$ \\
\hline Assault & $31(15.1)$ \\
\hline Traffic accident & $13(6.3)$ \\
\hline \multicolumn{2}{|l|}{ Mechanism of trauma, $n(\%)$} \\
\hline Blunt & $131(63.9)$ \\
\hline Penetrating & $65(31.7)$ \\
\hline Burn & $4(2)$ \\
\hline Chemical exposure & $2(1)$ \\
\hline Electric shock & $3(1.5)$ \\
\hline \multicolumn{2}{|l|}{ Injured hand, $\mathrm{n}(\%)$} \\
\hline Dominant & $98(47.8)$ \\
\hline Non-dominant & $107(52.2)$ \\
\hline Fracture, $\mathrm{n}(\%)$ & $38(18.5)$ \\
\hline Tendon damage, $n(\%)$ & 35 (17.1) \\
\hline Nerve damage, $n(\%)$ & $10(4.9)$ \\
\hline Amputation, $\mathrm{n}(\%)$ & $25(12.2)$ \\
\hline Permanent disability, n (\%) & $20(9.8)$ \\
\hline \multicolumn{2}{|l|}{ Treatment, $n(\%)$} \\
\hline NSAID & 94 (45.9) \\
\hline Primer suture & $28(13.7)$ \\
\hline Splint/Plaster & $31(15.1)$ \\
\hline Surgical intervention & $37(18)$ \\
\hline Stump closure & $15(7.3)$ \\
\hline
\end{tabular}

Male sex, penetrating trauma, the age group of 18-35 years, and night (00:00-08:00) trauma remained in the last step of the backward conditional method in multivariate logistic regression analysis. Male sex and penetrating trauma were found to be independent risk factors for permanent disability ( $p=0.012$ and $p<0.001$, respectively). Table 4 summarizes the results of logistic regression analysis

Of 25 patients who had to undergo amputation, stump closure was performed in 15 (60\%) patients, and 10 (40\%) patients required surgical intervention. Among 10 patients who underwent surgical intervention, the surgical procedure was successful in seven patients, and permanent disability developed in three patients. In these three patients, the cause of injury was occupational accidents, and all of them were observed in male patients and occurred in the age group of 18-35 years. In 9 out of 15 patients who underwent stump closure, the injury was on the fingertip, and there was no bone or tendon damage. Amputation was required in 18 of 20 patients with a permanent disability, and the remaining two patients, who had a home accident and tendon damage as a result of penetrating trauma, did not require amputation. Surgical intervention was unsuccessful in these two patients.
Table 2. Comparison of patients with and without amputation

\begin{tabular}{llll}
\hline & Without amputation & With amputation & p value \\
\hline Age group, years & & & $\mathbf{0 . 0 2 1}$ \\
$\begin{array}{l}\text { 18-35 } \\
\text { Others }\end{array}$ & $126(84.6)$ & $23(15.4)$ & \\
Sex & $54(96.4)$ & $2(3.6)$ & $\mathbf{0 . 0 3}$ \\
$\quad$ Male & $120(84.5)$ & $22(15.5)$ & \\
$\quad$ Female & $60(95.2)$ & $3(4.8)$ & 0.332 \\
Admission time & & & \\
00:00-08:00 & $18(78.3)$ & $5(21.7)$ & \\
08:00-16:00 & $96(88.9)$ & $12(11.1)$ & 0.404 \\
16:00-00:00 & $66(89.2)$ & $8(10.8)$ & \\
Dominant hand & & & \\
Yes & $88(89.8)$ & $10(10.2)$ & \\
No & $92(86)$ & $15(14)$ & \\
Cause of trauma & & & \\
Home accident & $50(84.7)$ & $9(15.3)$ & \\
Work accident & $43(82.7)$ & $9(17.3)$ & $<0.001^{*}$ \\
Fall & $48(96)$ & $2(4)$ & \\
Assault & $26(83.9)$ & $5(16.1)$ & \\
$\quad$ Traffic accident & $13(100)$ & $0(0)$ & \\
Mechanism of trauma & & $9(6.9)$ & \\
Blunt & $122(93.1)$ & $16(24.6)$ & \\
Penetrating & $49(75.4)$ & & \\
\hline Data were presented as $n(\%) .{ }^{*}$ The comparison was made between blunt and pene- \\
trating traumas, as there were no patients with amputation as a result of other \\
trauma mechanisms. & & &
\end{tabular}

Table 3. Comparison of patients with and without permanent disability

\begin{tabular}{|c|c|c|c|}
\hline & $\begin{array}{l}\text { Without permanent } \\
\text { disability }\end{array}$ & $\begin{array}{l}\text { With permanent } \\
\text { disability }\end{array}$ & $p$ value \\
\hline Age group, years & & & 0.018 \\
\hline $18-35$ & $130(87.2)$ & 19 (12.8) & \\
\hline Others & $55(98.2)$ & $1(1.8)$ & \\
\hline Sex & & & 0.034 \\
\hline Male & $124(87.3)$ & $18(12.7)$ & \\
\hline Female & $61(96.8)$ & $2(3.2)$ & \\
\hline Admission time & & & 0.103 \\
\hline 00:00-08:00 & $18(78.3)$ & $5(21.7)$ & \\
\hline 08:00-16:00 & $98(90.7)$ & $10(9.3)$ & \\
\hline $16: 00-00: 00$ & $69(93.2)$ & $5(6.8)$ & \\
\hline Dominant hand & & & 0.462 \\
\hline Yes & $90(91.8)$ & $8(8.2)$ & \\
\hline No & $95(88.8)$ & $12(11.2)$ & \\
\hline Cause of trauma & & & $0.03 *$ \\
\hline Home accident & $50(84.7)$ & $9(15.3)$ & \\
\hline Work accident & $44(84.6)$ & $8(15.4)$ & \\
\hline Fall & $50(100)$ & $0(0)$ & \\
\hline Assault & $28(90.3)$ & $3(9.7)$ & \\
\hline Traffic accident & $13(100)$ & $0(0)$ & \\
\hline Mechanism of trauma & & & $<0.001^{* *}$ \\
\hline Blunt & $128(97.7)$ & $3(2.3)$ & \\
\hline Penetrating & $48(73.8)$ & $17(26.2)$ & \\
\hline
\end{tabular}

Data were presented as $n(\%) .{ }^{*}$ Permanent disability in falls are statistically significantly lower in post-hoc analysis. ${ }^{* *}$ The comparison was made between blunt and penetrating traumas, as there were no patients with permanent disability as a result of other trauma mechanisms.

Table 4. Logistic regression analysis for permanent disability predictors

\begin{tabular}{llll}
\hline & Wald & Odds ratio $(95 \% \mathrm{Cl})$ & $p$ Value \\
\hline 18-35 years & 3.335 & $7.22(0.86-60.38)$ & 0.068 \\
Male sex & 6.255 & $7.63(1.55-37.55)$ & $\mathbf{0 . 0 1 2}$ \\
Penetrating traumas & 21.177 & $27.17(6.65-110.91)$ & $<0.001$ \\
00:00-08:00 & 3.358 & $4.61(0.89-23.66)$ & 0.067 \\
\hline
\end{tabular}

\section{Discussion}

Hand injuries generally affect the active young population, and these injuries can cause serious disability due to the complex anatomy of the hand $(7,10)$. In addition to the 
long recovery and rehabilitation period, temporary or permanent loss of productivity also constitutes an important economic burden $(4,11)$. Furthermore, loss of productivity negatively affects the psychosocial well-being of the person (12).

In this study, similar to previous literature reports, hand injuries mostly affected male individuals in the age group of $18-35$ years $(1,2,6,7)$. Only $30.7 \%$ female patients had hand injuries. While this rate is similar to that in developed countries such as the Netherlands and Denmark, it is higher than that in countries such as Nigeria and India $(10,11,13)$. The differences in the number of female patients presenting with hand injuries reflect the cultural diversity of the countries, the participation of women in business life, and the accessibility of health services. In our study, most patients with a permanent disability were male, and male sex was an independent risk factor for permanent disability.

Hand injuries can occur because of many factors, ranging from geographical conditions to the production areas of industrial establishments in the region. Home accidents and sports injuries seem to be the most common causes of hand injuries in countries where occupational health protocols are implemented and measures to prevent occupational accidents are developed $(11,14)$. However, in a study conducted in Nigeria, the most common cause of hand injuries was reported as traffic accidents (13). In Turkey, while home accidents and falls were the most common causes in studies carried out in Denizli and Ankara, occupational accidents were reported as the most common cause in a study from Afyon $(3,15,16)$. In our study, the most common cause of hand injuries was home accidents ( $n=59,28.8 \%$ ). Occupational accidents and falls were observed in $52(25.4 \%)$ and 50 (24.4\%) patients, respectively. Considering patients with minor hand injury who were not admitted to the ED in the fear of losing their job, occupational accidents constitute a significant part of hand injuries. Periodic training on occupational health and safety can reduce occupational accidents and related hand injuries, complications, and costs.

Penetrating trauma was reported as the most common mechanism of hand injuries in various countries $(1,7,13)$. However, in Turkey, blunt trauma was reported as the most common mechanism, and penetrating trauma was the cause of hand injury in $25-32.6 \%$ cases $(15,17)$. At home, penetrating trauma injuries may usually occur during kitchen work as superficial incisions, which do not result in a permanent disability. However, at workplaces, they usually occur when working with a machine with sharp or heavy metal parts and usually require amputation or lead to permanent disability $(7,9,10)$. In this study, most patients had blunt trauma similar to that reported in

other studies from Turkey. However, penetrating trauma was an independent risk factor for permanent disability. These results may be related to textile and heavy industry factories in our region. Prevention measures should be improved in such workplaces to reduce penetrating injuries and permanent disability.

The most dramatic complications of hand injuries are amputation and permanent disability. A study carried out in America reported that amputation was required in $2 \%$ of finger traumas (14). The incidence of amputation was $3 \%$ in a hand surgery clinic in France (18). In this study, we included patients with isolated hand injuries, and the amputation rate was $12.2 \%$, which seems higher than the values reported in the literature. With developments in microsurgery technology, the success rate of replantation after total amputation is more than $80 \%$. Although there is no absolute contraindication for undergoing microsurgery, delayed treatment can decrease the success rate $(18,19)$. In our study, all patients who needed amputation were admitted to the ED within the first hour of injury, and the replantation success rate was $70 \%$. The long-term effects of finger loss are not entirely clear. Bhat et al. reported a loss of $43.3 \%$ in grip strength and $33.6 \%$ in compression strength after finger loss. In addition, they reported an average recovery time of 13 weeks before the patient can start working again after a finger loss (20). Furthermore, direct and indirect costs resulting from hand injuries adversely affect healthcare costs (21). Therefore, it is important to identify injuries and risk factors resulting in an amputation or permanent disability. According to our results, male sex and penetrating trauma were independent risk factors for permanent disability in our region. In the city center, heavy industries are mainly in the textile sector. However, in rural areas, farming is generally the main source of income. Education seminars on penetrating trauma injuries could be conducted for people working in these sectors to prevent permanent disability after hand injuries.

This study has several limitations due to its retrospective nature. First, the number of patients included in the study was small because patients who had a minor hand injury were not admitted to the hospital. In addition, the causes of hand trauma could not be analyzed in detail. For example, it was not known whether occupational accidents resulted because of carelessness or lack of suitable equipment. The detailed mechanism of penetrating trauma injuries can be the main focus of future studies to identify and prevent hand injuries and related complications.

In conclusion, evaluation of hand injuries and related factors in our region is important because the results can vary between regions due to differences in lifestyle and working conditions. Male sex and penetrating trauma are independent risk factors for permanent disability among patients with isolated hand injuries. We believe that measures to prevent such injuries could reduce the rate of permanent disability and related mental and economic burden. 
Ethical Approval: Aksaray University School of Medicine Scientific Research Evaluation Committee (Date 18/12/2020 Number: 2020/13-48).

\section{Author Contributions:}

Concept: A.C...

Literature Review: A.Ç., i.K.

Design : A.C..

Data acquisition: I.K., M.A.E.

Analysis and interpretation: A.Ç., M.A.E.

Writing manuscript: A.Ç.

Critical revision of manuscript: A.Ç., M.A.E., I.K.

Conflict of Interest: Authors declared no conflict of interest.

Financial Disclosure: Authors declared no financial support.

\section{References}

1. Abebe MW. Common causes and types of hand injuries and their pattern of occurrence in Yekatit 12 Hospital, Addis Ababa, Ethiopia. Pan Afr Med J. 2019;33:142.

2. Ihekire O, Salawu SA, Opadele T. International surgery: causes of hand injuries in a developing country. Can $J$ Surg. 2010;53(3):161-6.

3. Şahin F, Akca H, Akkaya N, Zincir ÖD, Işik A. Cost analysis and related factors in patients with traumatic hand injury. J Hand Surg Eur Vol. 2013;38(6):673-9.

4. Rosberg HE, Carlsson KS, Dahlin LB. Prospective study of patients with injuries to the hand and forearm: costs, function, and general health. Scand J Plast Reconstr Surg Hand Surg. 2005;39(6):360-9.

5. Horton TC, Dias JJ, Burke FD. Social deprivation and hand injury. J Hand Surg Eur Vol. 200732(3):256-61.

6. Larsen CF, Mulder S, Johansen AM, Stam C. The epidemiology of hand injuries in The Netherlands and Denmark. Eur J Epidemiol. 2004;19(4):323-7.

7. Trybus M, Lorkowski J, Brongel L, Hladki W. Causes and consequences of hand injuries. Am J Surg. 2006;192(1):52-7.

8. Bhatti DS, Ain NU, Fatima M. Occupational Hand-Related Injuries at a Major Tertiary Care Burn and Reconstructive Center in Pakistan. Cureus. 2020;12(9):e10444.

9. Chow CY, Lee H, Lau J, Yu IT. Transient risk factors for acute traumatic hand injuries: a case-crossover study in Hong Kong. Occup Environ Med. 2007;64(1):47-52.

10. Gupta A, Gupta AK, Uppal SK, Mittal RK, Garg R, Aggarwal $N$. Demographic profile of hand injuries in an industrial town of north India: a review of $\mathbf{4 3 6}$ patients. Indian J Surg. 2013;75(6):454-61.

11. de Putter $C E$, van Beeck EF, Polinder $S$, Panneman MJ, Burdorf A, Hovius SE, et al. Healthcare costs and productivity costs of hand and wrist injuries by external cause: A population-based study in working-age adults in the period 2008-2012. Injury. 2016;47(7):1478-82.

12. De Sousa A, Sonavane $S$, Kurvey A, Kukreja $S$, Shah $N$. Psychological issues in hand trauma. Asian J Psychiatr. 2013;14(1):3-14

13. Olaitan $P$, Oseni $G$, Olakulehin $O$. Pattern of hand injuries in osogbo, South-west Nigeria. J West Afr Coll Surg. 2011;1(3):15-25.

14. Ootes D, Lambers KT, Ring DC. The epidemiology of upper extremity injuries presenting to the emergency department in the United States. Hand. 2012;7(1):18-22.

15. Aslan A, Aslan I, Özmeriç A, Atay T, Çaloğlu A, Konya MN Acil El Yaralanmalarında Deneyimlerimiz: 5 Yıllık Verilerin
Epidemiyolojik Değerlendirmesi. TAF Preventive Medicine Bulletin. 2013;12(5):563-70.

16. Oğuz $A B$, Polat $O$, Günalp $M$, Aygün $Z$, Genç $S$. Acil Servise Bașvuran El ve El Bileği Yaralanmalı Hastaların Maliyetlerinin İncelenmesi. Ankara Üniversitesi Tıp Fakültesi Mecmuası. 2017;70(3):195-9.

17. Şakrak T, Mangır S, Körmutlu A, Cemboluk Ö, Kıvanç Ö, Tekgöz A. 1205 El Yaralanmasi Olgusunun Retrospektif Analizi. Türk Plastik, Rekonstrüktif ve Estetik Cerrahi Dergisi (Turk J Plast Surg). 2010;17(3):134-8.

18. Pomares G, Coudane H, Dap F, Dautel G. Epidemiology of traumatic upper limb amputations. Orthop Traumatol Surg Res. 2018;104(2):273-6.

19. Ma Z, Guo F, Qi J, Xiang W, Zhang J. Effects of non-surgical factors on digital replantation survival rate: a metaanalysis. J Hand Surg Eur Vol. 2016;41(2):157-63.

20. Bhat AK, Acharya AM, Narayanakurup JK, Kumar B, Nagpal PS, Kamath A. Functional and cosmetic outcome of single-digit ray amputation in hand. Musculoskelet Surg. 2017;101(3):275-81.

21. Robinson LS, O'Brien L. Description and cost-analysis of emergency department attendances for hand and wrist injuries. Emerg Med Australas. 2019;31(5):772-9. 